\title{
Does High InFLATION CAUSE CENTRAL BANKERS TO LOSE THEIR JOB? EVIDENCE BASED ON A NEW DATA SET
}

\author{
AXEL DREHER \\ JAN-EGBERT STURM \\ JAKOB DE HAAN
}
CESIFO WORKING PAPER No. 2045
CATEGORY 6: MONETARY PoliCy AND InTERnAtional FinANCE JULY 2007

An electronic version of the paper may be downloaded

- from the SSRN website:

- from the RePEc website:

wWw.SSRN.com

- from the CESifo website:

www.RePEc.org

www.CESifo-group.de 


\title{
DOES High INFLATION CAUSE CENTRAL BANKERS TO LOSE THEIR JOB? EVIDENCE BASED ON A NEW DATA SET
}

\begin{abstract}
This paper introduces new data on the term in office of central bank governors in 137 countries for 1970-2004. Our panel models show that the probability that a central bank governor is replaced in a particular year is positively related to the share of the term in office elapsed, political and regime instability, the occurrence of elections, and inflation. The latter result suggests that the turnover rate of central bank governors (TOR) is a poor indicator of central bank independence. This is confirmed in models for cross-section inflation in which TOR becomes insignificant once its endogeneity is taken into account.

JEL Code: E5.
\end{abstract}

Keywords: central bank governors, central bank independence, inflation.

Axel Dreher

ETH Zurich

KOF Swiss Economic Institute

WEH D4

Weinbergstr. 35

8092 Zurich

Switzerland

mail@axel-dreher.de
Jan-Egbert Sturm

ETH Zurich

KOF Swiss Economic Institute

WEH D4

Weinbergstr. 35

8092 Zurich

Switzerland

sturm@kof.ethz.ch

Jakob de Haan

Department of Economics

University of Groningen

P.O. Box 800

9700 AV Groningen

The Netherlands

jakob.de.haan@rug.nl

June 2007 


\section{Introduction}

In this paper we examine which political and economic factors affect the likelihood that a central bank governor will be replaced. We present new data on the term in office of central bank governors for 137 countries covering the period 1970-2004, thereby substantially extending previous datasets, both regarding the number of countries and the number of years covered. ${ }^{1}$ We estimate conditional Logit models of the probability that the central bank governor will be replaced. Our results show that the share of the current term in office elapsed, high levels of political and regime instability, the occurrence of elections, and inflation increase the probability of a turnover.

Our main contribution is that we criticize the use of the so-called turnover rate of central bank governors (TOR) as an indicator of central bank independence (CBI). ${ }^{2}$ To examine whether there is any relationship between CBI and inflation, one needs an indicator measuring the extent to which the monetary authorities are independent from politicians. Most empirical studies use an indicator based on central bank laws in place. However, legal measures of CBI may not reflect the true relationship between the central bank and the government (Forder, 1996 and Mangano, 1998). Especially in countries where the rule of law is less strongly embedded in the political culture, there can be wide gaps between the formal, legal institutional arrangements and their practical impact (Walsh, 2005). This is particularly likely in many developing economies. Cukierman (1992) argues that the TOR may therefore be a better proxy for CBI in these countries than measures based on central bank laws. The TOR is based on the presumption that, at least above some threshold, a higher turnover of central bank governors indicates a lower level of independence. Various studies report that countries that experienced rapid turnover among their central bank heads also tended to experience high rates of inflation (see, for instance, Cukierman, 1992). This is a case, however, in which causality is difficult to evaluate; is inflation high because of political interference that leads to rapid turnover of central bank officials? Or are central bank officials tossed out because they can't keep inflation down? (Walsh, 2005). In the latter case, the TOR is a poor indicator of CBI. ${ }^{3}$

\footnotetext{
${ }^{1}$ The datasets of Cukierman (1992) and De Haan and Kooi (2000) are the most widely used previous datasets.

${ }^{2}$ See Berger et al. (2001) for a survey of the literature on central bank independence.

${ }^{3}$ A few studies have sounded a warning that conclusions on the relationship between inflation and the TOR are highly sensitive to influential observations. De Haan and Kooi (2000) and Sturm and De Haan (2001) report that the TOR indicator only becomes significant if high inflation countries are added to the sample. This suggests that causality may run from inflation to turnovers rather than the other way round.
} 
Our empirical results suggest that using the TOR as a proxy for CBI is problematic when it comes to measuring the impact of central bank independence on inflation. Since inflation increases the likelihood that the central bank governor will be replaced, turnovers are endogenous to inflation. This is confirmed in models for cross-section inflation differentials in which the TOR becomes insignificant once its endogeneity is taken into account.

The remainder of the paper is structured as follows. Section 2 describes our data and section 3 discusses the methodology used. Section 4 presents our estimation results for the likelihood that a central bank governor will be replaced, while section 5 contains the models for cross-section inflation. The final section offers some concluding comments.

\section{Data}

The database contains information on the term in office of the central bank governor for 137 countries covering the period 1970-2004. Most information was received directly from central banks. Some central banks provide data on previous governors on their homepage, while for many other central banks we got the information by writing emails and letters. A second source is Morgan Stanley Dean Witter's Central Bank Directory. Our data cover all geographic regions fairly well. While we tried to get data going back as far as 1970, we did not always succeed either because data were not available for the entire period or because countries came into existence after 1970. Table A1 in the Appendix shows the countries and periods for which we have information, as well as the number of times the central bank governor was replaced during those periods and the average TOR. 
Figure 1. Frequency distribution of number of governor changes (\# countries)

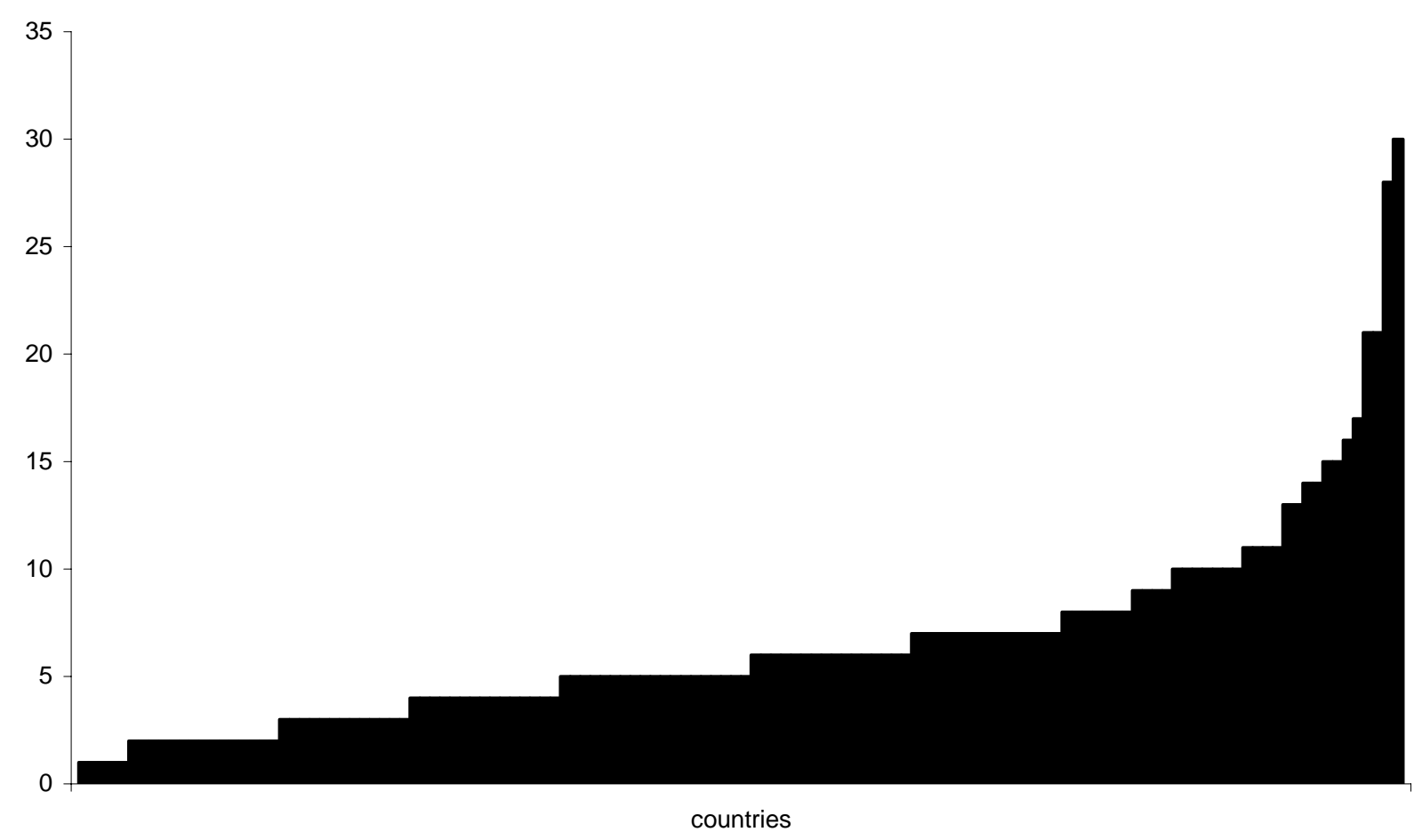

Figure 1 shows the frequency distribution of the number of governor changes during the time period for which we have information, while Figure 2 presents the average TOR for the countries in our sample. According to our dataset, on average a central bank governor remained in office for 3.6 years. On average, a turnover occurred in 22 percent of the country-years. Argentina (with an average TOR of 0.86) and Ecuador (average 0.80 ) have the highest turnover rates of the countries in our sample. 
Figure 2. Average turnover rate for the countries in our sample

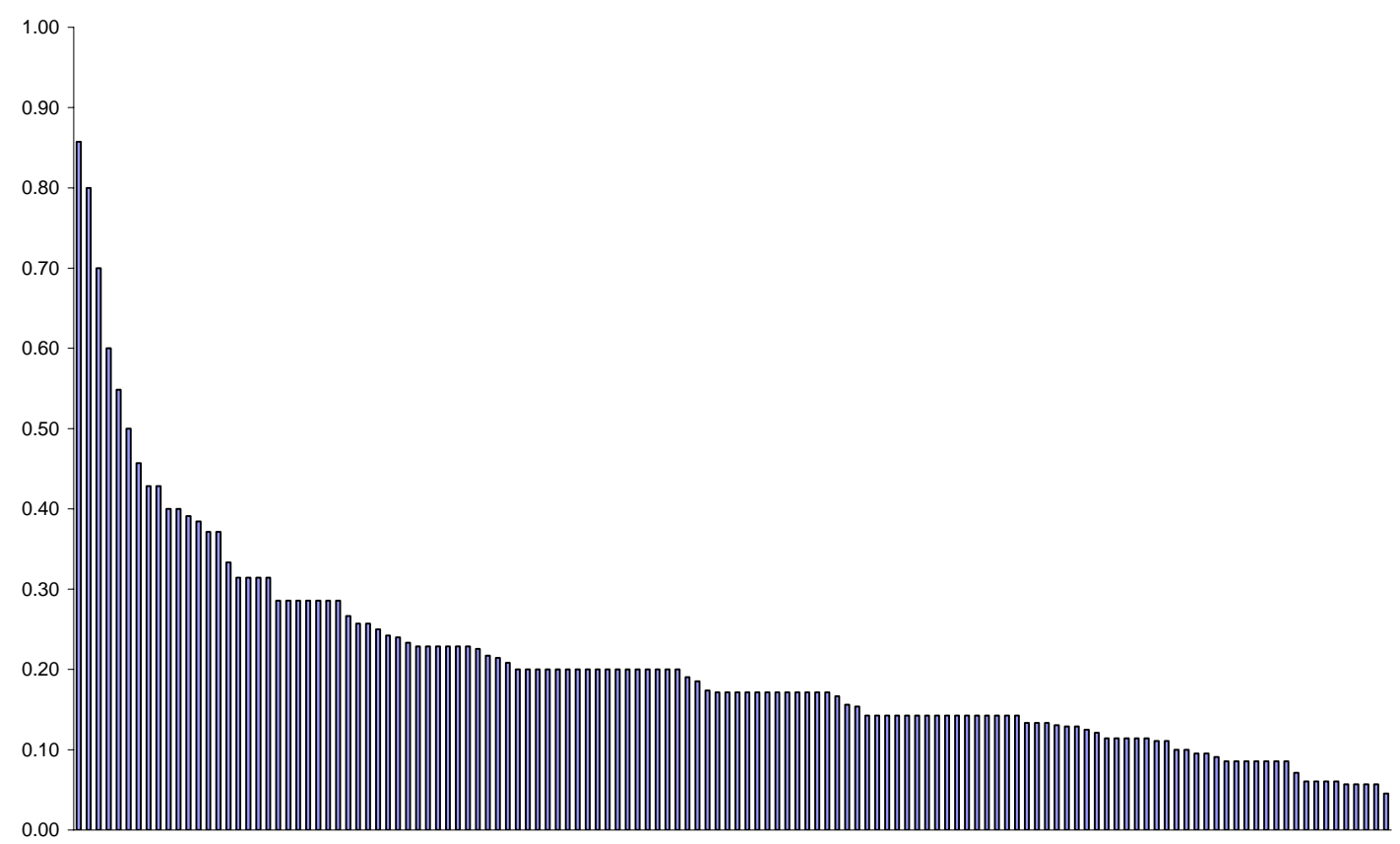

Figure 3 shows the yearly average turnover for our full sample. It is interesting that after 1995, when many countries increased the legal independence of their central bank, the average number of turnovers decreases. ${ }^{4}$ Figure 4 shows the average turnover for various regions, using the World Bank classification of regions. It becomes clear that there is quite some variation across regions. For instance, in Latin-America and SubSaharan Africa the turnover decreases at the end of the sample period, but there is no clear trend in some of the other regions, like Europe and Central Asia.

\footnotetext{
${ }^{4}$ This result is not driven by the increasing number of countries in our sample in more recent years. When restricting the sample to countries with at least 30 observations, the overall picture looks very much alike.
} 
Figure 3. Average annual turnover rate, 1970-2004

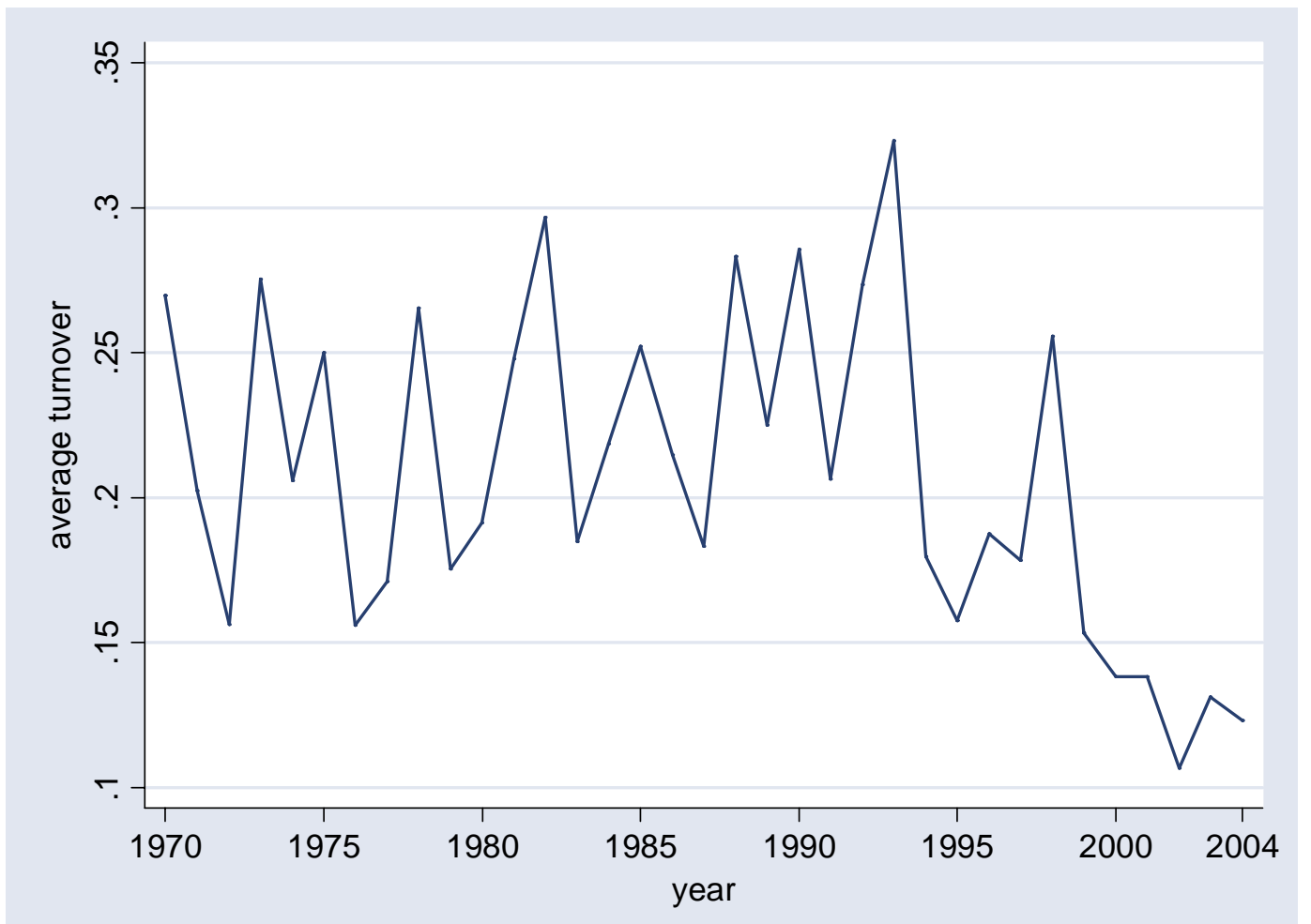

Figure 4. Average turnover in various regions, 1970-2004
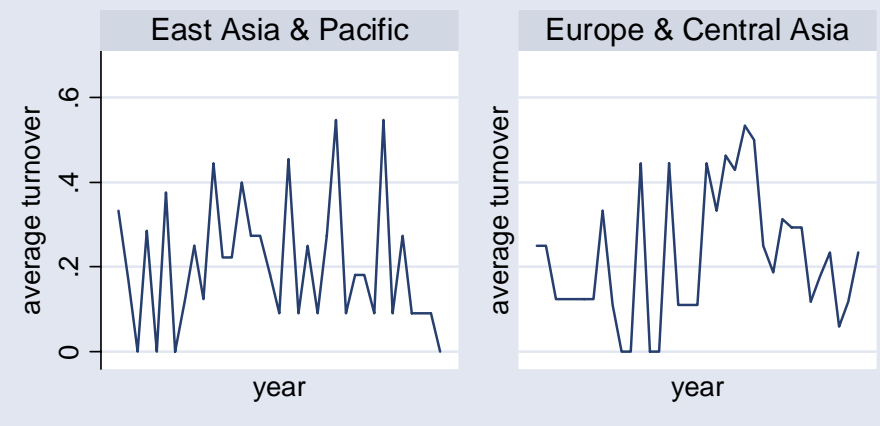

Latin America \& Caribbean
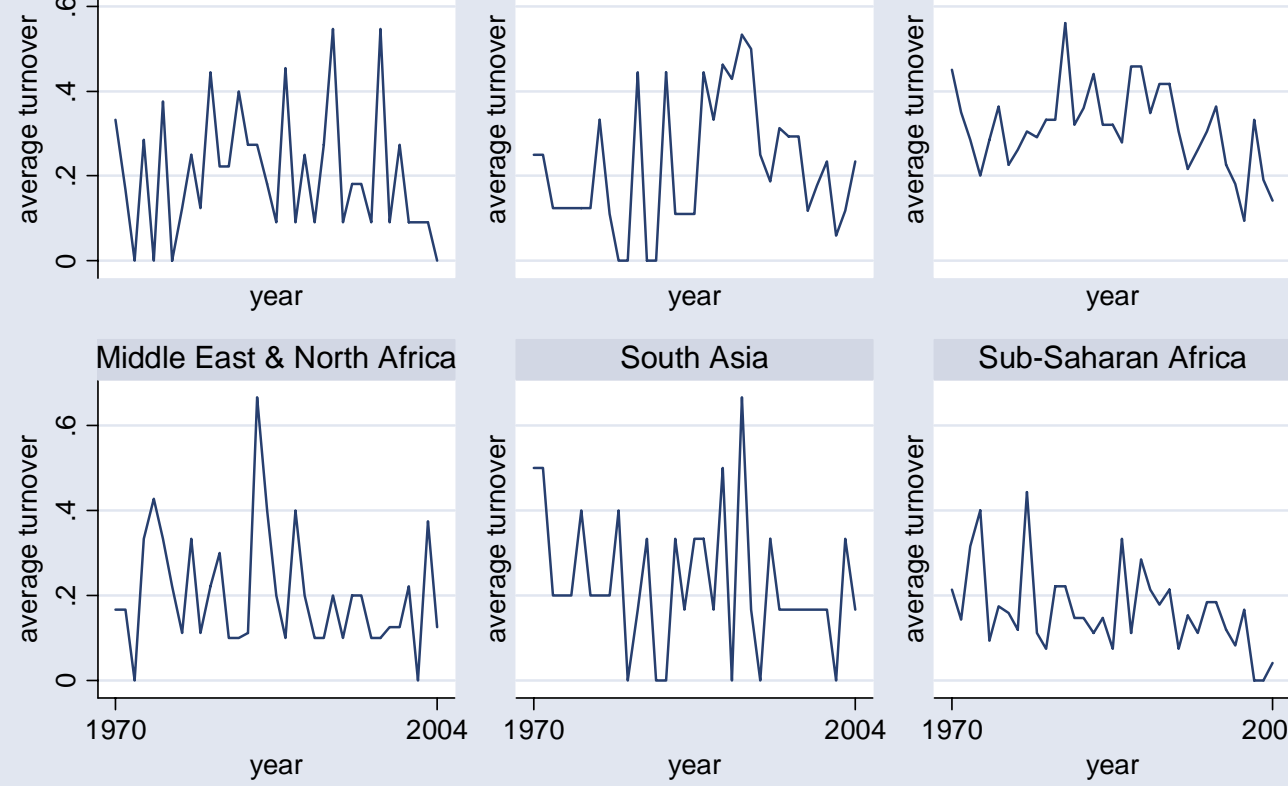

Sub-Saharan Africa

Graphs by region

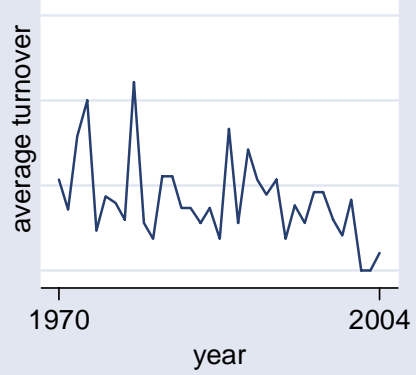


Our dataset also includes information on the legal term in office of the central bank governor. Unfortunately, data is not available for all country-years in our sample. We obtained data on regular office terms for 91 countries, for an average of 31 years, ranging from 8-36. In some cases the governor's term in office is unlimited, and the most likely reason for a turnover is retirement due to age.

\section{Methodology}

According to Cukierman (1992), high and sustained inflation leads to the evolution of automatic or semi-automatic accommodative mechanisms, like indexation of contracts in the labour and capital markets, that may undermine central bank independence. Alternatively, it may be argued that a high inflation rate may cause the replacement of the central bank governor due to dissatisfaction with this policy outcome (Walsh, 2005). Both arguments, although fundamentally different in their reasoning, lead to the hypothesis that the higher the rate of inflation the shorter the term in office of the governor will be. We test this hypothesis using our new dataset.

We first estimate a model for the likelihood that a central bank governor is being replaced. Our dependent variable is binary, and takes the value one if the central bank governor was replaced in a particular year and country. We estimate our model employing conditional fixed effects Logit. In case of binary choice variables with panel data we observe:

$$
\begin{array}{lll}
y_{i t}=1 & \text { if } & y_{i t}^{*}>0 \\
y_{i t}=0 & \text { if } & y_{i t}^{*} \leq 0
\end{array}
$$

where: $y_{i t}^{*}=x^{\prime}{ }_{i t} \beta+\alpha_{i}+v_{i t}$. This function can be interpreted as the inclination of the government to replace the central bank governor, which is dependent on observed variables $(x)$, unobserved individual (country) characteristics $(\alpha)$ and a random error term $(v)$. The probability that we observe a replacement is:

$$
P\left(y_{i t}=1\right)=P\left(y_{i t}^{*}>0\right)=P\left(v_{i t}>-x_{i t}^{\prime} \beta-\alpha_{i}\right)=F\left(x_{i t}^{\prime} \beta+\alpha_{i}\right) .
$$


In a fixed effects context, the number of parameters increases with the number of countries. This is known as the incidental parameters problem. Chamberlain (1980) shows that it is impossible to estimate the parameters of this binary choice model consistently and he therefore proposes a method to circumvent this problem, i.e. conditional Logit estimation. The idea of this approach is to condition the likelihood function on a minimal sufficient statistic for the fixed effects. Chamberlain argues that $\sum_{t=1}^{T} y_{i t}$ is such a minimum sufficient statistic. The conditional likelihood function can now be written as:

$$
L=\prod_{i=1}^{N} P\left(y_{i 1}, \cdots, y_{i T} \mid \sum_{i=t}^{T} y_{i t}\right)
$$

The probability of the observed replacement of the central bank governor (by construction) no longer depends on the fixed effects and hence the coefficients of the variables of interest can be estimated consistently. In essence, the conditional fixed effects Logit estimator compares all observations within a given country when there is a replacement of the central bank governor with all the observations when there is no such change. ${ }^{5}$

Since some of the data are not available for all country-years, the panel data are unbalanced. All explanatory economic variables are lagged by one year to avoid simultaneity. The explanatory variable of prime interest, i.e. the inflation rate $p$, is transformed by the formula $(\mathrm{p} / 100) /(1+(\mathrm{p} / 100)=\pi)$ to reduce the influence of extreme observations. The estimated model is:

$$
\text { govchange }_{i, t}=\alpha+\beta_{1} \text { shelap }_{i, t-1}+\beta_{2} \pi_{t-1}+\beta_{3} X_{i, t-1}+\eta_{i}+u_{i, t} \text {, }
$$

where govchange is one in year $t$ when at least one change of the central bank governor occurred in that year; shelap is the share of the governor's legal term in office elapsed, and $X$ is a vector of control variables. $\eta_{i}$ are the country dummies and $u_{i t}$ is an i.i.d. disturbance.

\footnotetext{
${ }^{5}$ There is one obvious drawback in employing the conditional fixed effects Logit model: we cannot include explanatory variables that do not vary over time.
} 
We include the share of the governors' term in office as stipulated by the central bank law that has elapsed. For instance, if the legal term in office is 8 years, and the governor has been in office for 4 years this variable is 0.5 . However, in case of an indefinite or unknown term in office it is not obvious how to construct this variable. In those cases we presume that the maximum legal term in office is 8 years. ${ }^{6}$

To determine which control variables should be taken up, we have screened the literature to come up with a long list of potential control variables. ${ }^{7}$ The variables are listed in Table A2 in the Appendix. We apply a general to specific approach to come up with our base model. Finally, we employ the so-called Extreme Bounds Analysis (EBA) to examine the robustness of our findings. This approach can be explained as follows. We estimate equations of the following general form:

$$
\text { govchange }_{i, t}=\alpha M_{i, t}+\beta F_{i, t}+\gamma Z_{i, t}+u_{i, t} \text {, }
$$

where $M$ is a vector of 'standard' explanatory variables; $F$ is the variable of interest (in our case: recent inflation); $Z$ is a vector of up to three (here we follow Levine and Renelt, 1992) possible additional explanatory variables, which according to the literature may be related to the dependent variable; and $u$ is an error term. We use the $\mathrm{CDF}(0)$ test suggested by Sala-i-Martin (1997), which is based on the fraction of the cumulative distribution function (CDF) lying on each side of zero. $\mathrm{CDF}(0)$ indicates the larger of the areas under the density function either above or below zero; in other words, regardless of whether this is $\operatorname{CDF}(0)$ or $1-\operatorname{CDF}(0)$. So $\operatorname{CDF}(0)$ will always be a number between 0.5 and 1.0. Following Sala-i-Martin, a variable is considered to be robust if the $\operatorname{CDF}(0)$ test statistic $>0.90 .^{8}$

\footnotetext{
${ }^{6}$ We have also experimented with two alternatives. First, we assumed the term in office for countries with indefinite or unknown term in office to be equal to the average time in office in our sample, i.e. 3.6 years. Second, we took the average of those countries that have specified the term in office of the CB governor in their central bank law (5 years). It turned out that our main results are very similar under both alternatives (results available on request).

${ }^{7}$ Those few studies that explicitly estimate models explaining cross-country variation in CBI suggest various control variables. A good example is Stasavage and Keefer (2003) who argue that political replacement of a central bank governor is more likely in the presence of multiple political veto players; to take this argument into account we employ Henisz's (2000) data on political constraints. Frankel (2005) reports that in the year following a currency crash the finance minister or central bank governor - whoever held the office of the country's governor of the IMF - often lost his job. To take this argument into account, we employ a dummy variable reflecting the occurrence of a currency crisis. A very detailed motivation and description of the control variables is provided in Dreher et al. (2007).

${ }^{8}$ Recently, Sala-i-Martin et al. (2004) proposed a so-called Bayesian Averaging of Classical Estimates (BACE) approach to check the robustness of different explanatory variables in growth regressions. This approach builds upon the procedure suggested by Sala-i-Martin (1997) in the sense that different
} 
In the final part of our analysis we estimate panel and cross-section models for inflation using a model similar to that of Campillo and Miron (1997). The models are first estimated by OLS, assuming that the TOR is exogenous. Next, we take the endogeneity of the TOR into account, using the results of our conditional fixed effects Logit model for the likelihood that a central bank governor is being replaced.

\section{Results for the logit model}

Table 1 shows the estimation results for equation (4). The specification is chosen on the basis of a general to specific approach applied to various possible control variables - shown in Table A2 of the Appendix - that all have been suggested to affect the term in office of central bank governors (see Dreher et al. 2007 for an extensive discussion). The estimation results suggest that five variables are significant determinants of the likelihood that a central bank governor will be replaced: the share of the legal term in office that has elapsed, the share of political veto players who drop, a post-election variable measuring the part of a year which is within 12 months after an election, a dummy for coups d'etats, and - most important for our analysis (lagged) inflation.

Past inflation increases the probability that the central bank governor will be replaced at the five percent level of significance. According to the marginal effect, a percentage point increase in inflation increases the probability of a turnover by 21 percent.

specifications are estimated (by OLS) to check the sensitivity of the coefficient estimate of the variable of interest. The biggest disadvantages of the BACE approach are the need of having a balanced data set, i.e. an equal number of observations for all regressions (due to the chosen weighting scheme) and the restriction of limiting the list of potential variables to be less than the number of observations. 
Table 1. The impact of inflation on the likelihood

that a central bank governor will be replaced

\begin{tabular}{lc}
\hline & $(1)$ \\
\hline Share of term elapsed & 0.825 \\
& $\left(7.97^{* * *}\right)$ \\
Percentage of veto players & 0.340 \\
who drop & $\left(1.92^{*}\right)$ \\
Election & 0.650 \\
& $\left(3.93^{* * *}\right)$ \\
Coups & 1.040 \\
& $\left(3.05^{* * *}\right)$ \\
Inflation, t-1 & 1.020 \\
& $\left(2.32^{* *}\right)$ \\
& \\
\hline Method & Logit \\
Fixed effects & yes \\
Prob $>$ Chi2 & 0.00 \\
Number of countries & 119 \\
Number of observations & 2339 \\
\hline
\end{tabular}

Table 2 shows the outcome of the EBA. We have employed two specifications for the M-vector. In the restricted model, only the share of the legal term if office that has elapsed is included in the M-vector, while the remaining variables listed in Table A2 in the Appendix are included in the Z-vector. In the full model, all variables arising from the general-to-specific approach as shown in Table 1 are taken up in the $M$ vector, while the remaining variables are in the Z-vector. As can be seen, according to both specifications, the $\operatorname{CDF}(0)$ test indicates that inflation is robustly related to the likelihood that the central bank governor will be replaced.

Table 2. Is past inflation robustly related to the likelihood that $C B$ governor is being replaced?

\begin{tabular}{|l|l|}
\hline & CDF(0) \\
\hline Restricted model & 0.96 \\
\hline Full model & 0.91 \\
\hline
\end{tabular}

Now that we have shown that inflation has a robust impact on the likelihood that a central bank governor will be replaced, we will examine in the next section the 
implications of this finding for models explaining cross-country inflation differentials using the TOR as a procy for CBI.

\section{Inflation models}

In this section we report panel and cross-section models for inflation. The dependent variable is our transformed inflation variable. Following Campillo and Miron (1997), we include the following explanatory variables:

- An indicator for openness (OPEN, defined as sum of export and import in relation to GDP) over the period under consideration (taken from the World Bank's World Development Indicators).

- The log of the level of GDP per capita (GDPCAP) at the beginning of the period (again from the World Development Indicators).

- A proxy for political instability (PI), measured by the first principal component of the number of assassinations, strikes, guerrilla warfare, major crises, riots, and revolutions in a particular country and year taken from the Databanks International (2005) Cross-National Time-Series Data Archive.

- An exchange rate dummy, which is one if the country's exchange rate is classified as fixed according to the de-facto classification of exchange rate regimes in Levy-Yeyati and Sturzenegger (2005), and zero otherwise. This variable is used to examine the impact of the exchange rate regime and is denoted as XRATE.

As it is well-known that the TOR may not be a good indicator of CBI in industrial countries (Cukierman, 1992), we not only include the TOR in the model, but also its interaction with a dummy that is one if the country concerned is an OECD country and zero otherwise.

The first column of Table 3 shows the results for a panel, using the averages or starting values of the variables for the periods 1970-79, 1980-89 and 1990-2004. In line with most previous studies, the coefficient of the TOR is positive and highly significant. Figure 5 shows recursive regressions of this model; the 30 countries with the lowest inflation are always included - additional countries are added one by one. In line with the findings of Sturm and De Haan (2001), the effect of the TOR only becomes significant if high-inflation countries are included. This suggests that the causality may run from inflation to turnovers rather than the other way round. Therefore, we next treat 
the TOR as an endogenous variable using the variables that we found to be significant determinants of the likelihood that a central bank governor will be replaced as instruments. F-tests on the joint significance of our instruments (the average share of the legal term in office that has elapsed, percentage of veto players who drop, elections, and number of coups) in the first-stage regressions show that they are good predictors of turnovers, conditional on the full set of exogenous variables in the system. As the Ftests reported in Table 3 indicate, the Staiger-Stock critical value of 10 is easily passed in all regressions. In all regressions, the overidentifying restrictions are also accepted at the five percent level of significance at least.

The results are shown in column (2) of Table 3. It turns out that the TOR no longer has a significant impact on inflation. The same conclusion is reached for the cross-section models shown in columns (3) - (8) of Table 3 . If the TOR is used in the OLS regression, its coefficient is generally significantly different from zero. However, in the 2SLS models, the TOR never has a significant impact on inflation. 
Table 3. Inflation: cross-country and panel models, 1970-2004

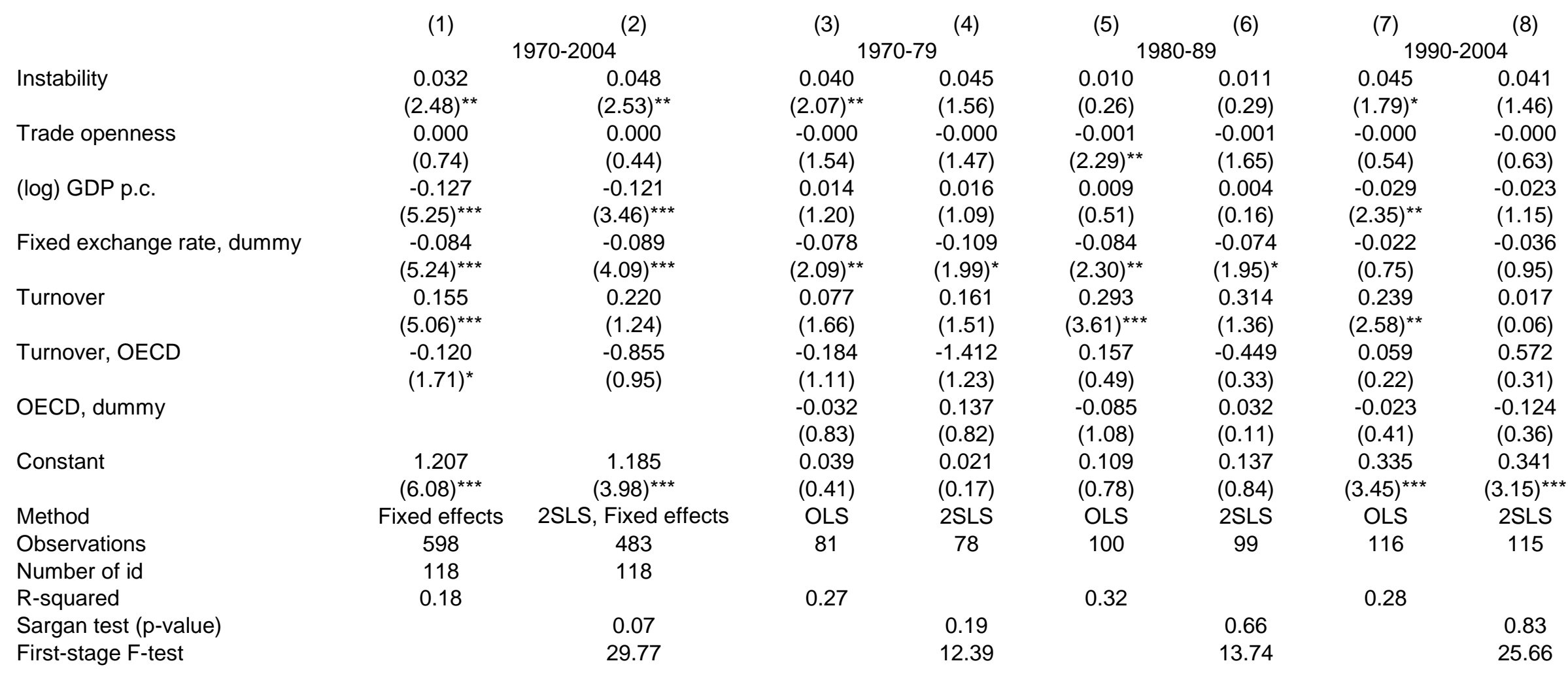

Absolute value of $\mathrm{t}$ statistics in parentheses

* significant at $10 \%$; ** significant at $5 \%$; $* \star *$ significant at $1 \%$

Note: In 2SLS, Turnover and ist interaction with the OECD dummy are instrumented with the average share of term elapsed, percentage of veto players who drop, elections, and number of coups. 
Figure 5. Recursive regressions of the model shown in column (1) of Table 3

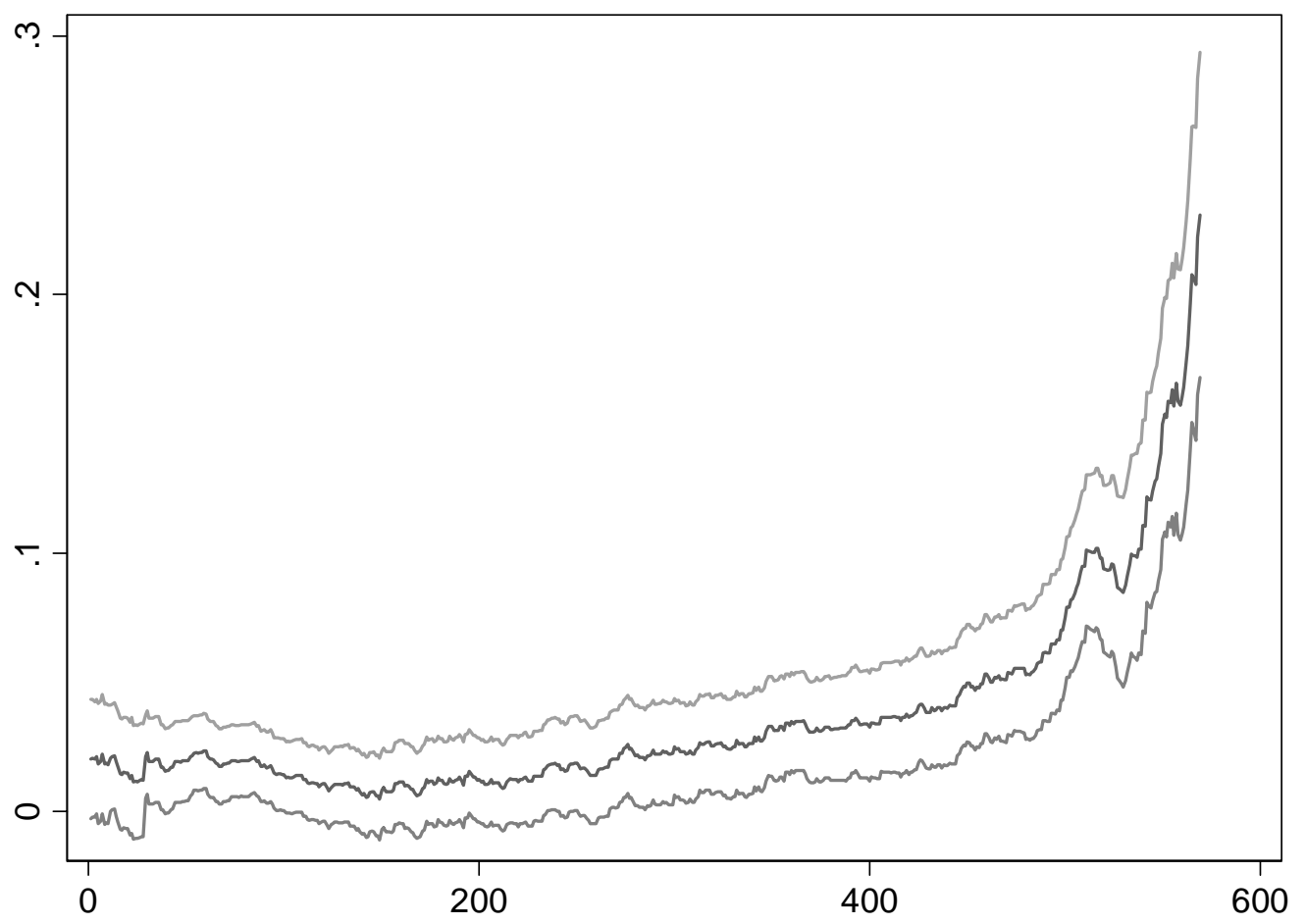

\section{Concluding comments}

Using a new data set on the term in office of central bank governors in 137 countries covering the period 1970-2004, we find that inflation increases the likelihood that the central bank governor will be replaced. This has implications for the so-called turnover rate of central bank governors, which is often used as an indicator of central bank independence (CBI). One objection that has been raised against the turnover rate as a proxy for $\mathrm{CBI}$ is that it may be endogenous to economic performance as causality may well run in the opposite direction. Our findings support this critique. In panel and cross-section models for inflation the turnover rate becomes insignificant once its endogeneity is taken into account. 


\section{References}

Berger, H., J. De Haan and S.C.W. Eijffinger, 2001, Central Bank Independence: An Update of Theory and Evidence, Journal of Economic Surveys 15, 3-40.

Brumm, H.J., 2000, Inflation and Central Bank Independence: Conventional Wisdom Redux, Journal of Money, Credit, and Banking 32(4), 807-819.

Campillo, M. and J.A. Miron (1997), Why does inflation differ across countries?, In: Reducing Inflation: Motivation and Strategy, Romer, C.D. and D.H. Romer (eds.), Chicago, University of Chicago Press, pp. 335-357.

Chamberlain, G., 1980, Analysis of covariance with qualitative data, Review of Economic Studies, 47, 225-238.

Cukierman, A., 1992, Central Bank Strategy, Credibility, and Independence, Cambridge. (MIT Press, Cambridge, MA).

Databanks International, 2005, Cross-National Time-Series Data Archive, 1815-2003, Binghamton, NY.

Dreher, A., J. De Haan, and J-E. Sturm, 2007, When is a central bank governor replaced?, paper presented at the 2007 First World Public Choice Conference, Amsterdam, April 2007.

Forder, J., 1996, On the assessment and implementation of 'institutional' remedies, Oxford Economic Papers, 48, 39-51.

Henisz, W. J. (2000), The Institutional Environment for Economic Growth, Economics and Politics, 12(1), 1-31.

Levine, R. and D. Renelt, 1992, A sensitivity analysis of cross-country growth regressions, American Economic Review, 82, 942-963.

Levy-Yeyati, Eduardo and Federico Sturzenegger, 2005, Classifying exchange rate regimes: Deeds vs. words, European Economic Review, 49(6), 1603-1635.

Mangano, G. (1998), Measuring central bank independence: A tale of subjectivity and of its consequences, Oxford Economic Papers, 50, 468-492.

Sala-i-Martin, X., 1997, I just ran two millions regressions, American Economic Review, 87(2), 178-183.

Sala-i-Martin, X., G. Doppelhofer and R.I. Miller, 2004, Determinants of Long-term Growth: A Bayesian Averaging of Classical estimates (BACE) Approach, American Economic Review, 94(4), 813-835. 
Stasavage, D. and P. Keefer (2003), The limits of delegation: Veto players, central bank independence, and the credibility of monetary policy, American Political Science Review, 97(3), 407-424. 
Appendix Table A1. A summary of the dataset on the turnover rate of central bank

\begin{tabular}{|c|c|c|c|c|c|c|c|}
\hline Country & period & \# changes & av. TOR & Country & period & \# changes & av. TOR \\
\hline Albania & $1993-2005$ & 5 & 0,38 & Kenya & $1971-2005$ & 4 & 0,11 \\
\hline Algeria & $1976-2005$ & 6 & 0,20 & Korea, Dem. Rep. & $1971-2005$ & 10 & 0,29 \\
\hline Argentina & $1971-2005$ & 30 & 0,86 & Kuwait & $1971-2005$ & 3 & 0,09 \\
\hline Australia & $1971-2005$ & 4 & 0,11 & Latvia & $1992-2005$ & 2 & 0,14 \\
\hline Austria & $1971-2005$ & 6 & 0,17 & Lebanon & $1971-2005$ & 7 & 0,20 \\
\hline Bahamas, The & $1975-2005$ & 4 & 0,13 & Lesotho & 1979-2005 & 5 & 0,19 \\
\hline Bahrain & $1971-2005$ & 4 & 0,11 & Libya & $1982-1996$ & 4 & 0,27 \\
\hline Bangladesh & $1973-2005$ & 8 & 0,24 & Lithuania & $1991-2005$ & 3 & 0,20 \\
\hline Barbados & $1973-2005$ & 4 & 0,12 & Luxembourg & 1999-2005 & 1 & 0,14 \\
\hline Belgium & $1971-2005$ & 6 & 0,17 & Madagascar & $1974-2005$ & 3 & 0,10 \\
\hline Belize & $1983-2005$ & 4 & 0,19 & Malawi & $1971-2005$ & 7 & 0,20 \\
\hline Bermuda & $1971-2005$ & 6 & 0,17 & Malaysia & $1971-2005$ & 5 & 0,14 \\
\hline Bhutan & $1983-2005$ & 3 & 0,13 & Malta & $1971-2005$ & 8 & 0,23 \\
\hline Bolivia & $1971-2005$ & 21 & 0,70 & Mauritius & $1971-2005$ & 4 & 0,11 \\
\hline Bosnia and Herzegovina & $1998-2005$ & 1 & 0,13 & Mexico & $1971-2005$ & 7 & 0,20 \\
\hline Botswana & $1976-2005$ & 7 & 0,23 & Mongolia & $1971-2005$ & 6 & 0,17 \\
\hline Brazil & $1971-2005$ & 21 & 0,60 & Morocco & $1971-2005$ & 3 & 0,09 \\
\hline Bulgaria & $1971-2005$ & 7 & 0,20 & Mozambique & $1976-2005$ & 4 & 0,13 \\
\hline Burundi & $1978-2005$ & 4 & 0,14 & Namibia & $1991-2005$ & 3 & 0,20 \\
\hline Canada & $1971-2005$ & 5 & 0,14 & Nepal & $1971-2005$ & 7 & 0,20 \\
\hline Cape Verde & 1977-1998 & 2 & 0,09 & Netherlands & $1971-2005$ & 2 & 0,06 \\
\hline Central African Republic & 1971-2005 & 3 & 0,09 & Netherlands Antilles & $1971-2005$ & 5 & 0,14 \\
\hline Chad & $1973-2005$ & 2 & 0,06 & New Zealand & 1971-2005 & 5 & 0,14 \\
\hline Chile & 1971-2005 & 15 & 0,43 & Nicaragua & $1980-1997$ & 9 & 0,50 \\
\hline China & $1971-2005$ & 8 & 0,23 & Nigeria & $1971-2005$ & 5 & 0,14 \\
\hline Colombia & $1971-2005$ & 5 & 0,14 & Norway & $1971-2005$ & 5 & 0,14 \\
\hline Congo, Dem. Rep. & $1973-2005$ & 2 & 0,06 & Pakistan & $1971-2005$ & 10 & 0,29 \\
\hline Costa Rica & 1971-2005 & 16 & 0,46 & Panama & 1971-1988 & 2 & 0,11 \\
\hline Croatia & $1991-2005$ & 3 & 0,20 & Paraguay & $1971-2005$ & 8 & 0,23 \\
\hline Cyprus & $1971-2005$ & 2 & 0,06 & Peru & 1971-1993 & 9 & 0,39 \\
\hline Czech Republic & $1971-2005$ & 7 & 0,20 & Philippines & $1971-2005$ & 6 & 0,17 \\
\hline Denmark & $1971-2005$ & 5 & 0,14 & Poland & $1971-2005$ & 11 & 0,31 \\
\hline Djibouti & $1978-1998$ & 2 & 0,10 & Portugal & $1971-2005$ & 11 & 0,31 \\
\hline Dominican Republic & $1971-2005$ & 14 & 0,40 & Qatar & 1975-1998 & 1 & 0,10 \\
\hline Ecuador & $1971-2005$ & 28 & 0,80 & Romania & 1971-2005 & 6 & 0,17 \\
\hline Egypt, Arab Rep. & $1971-2005$ & 7 & 0,20 & Russian Federation & $1991-2005$ & 5 & 0,33 \\
\hline El Salvador & $1971-2005$ & 13 & 0,37 & Samoa & $1985-2005$ & 2 & 0,10 \\
\hline Equatorial Guinea & $1973-2005$ & 2 & 0,06 & Saudi Arabia & $1971-2005$ & 2 & 0,06 \\
\hline Estonia & $1991-2005$ & 2 & 0,13 & Serbia and Montenegro & 1971-2005 & 10 & 0,29 \\
\hline Ethiopia & $1971-2005$ & 7 & 0,20 & Seychelles & $1979-2005$ & 3 & 0,11 \\
\hline Fiji & $1975-2005$ & 7 & 0,23 & Singapore & $1971-2005$ & 8 & 0,23 \\
\hline Finland & 1971-2005 & 6 & 0,17 & Slovak Republic & $1994-2005$ & 2 & 0,17 \\
\hline France & $1971-2005$ & 6 & 0,17 & Slovenia & $1992-2005$ & 1 & 0,07 \\
\hline Gabon & $1973-2005$ & 2 & 0,06 & Solomon Islands & $1984-2005$ & 1 & 0,05 \\
\hline Gambia, The & 1973-1998 & 4 & 0,15 & South Africa & 1971-2005 & 3 & 0,09 \\
\hline Georgia & $1978-2005$ & 7 & 0,25 & Spain & $1971-2005$ & 5 & 0,14 \\
\hline Germany & $1971-2005$ & 7 & 0,20 & Sri Lanka & $1971-2005$ & 6 & 0,17 \\
\hline Ghana & $1971-2005$ & 6 & 0,17 & Sudan & $1971-2005$ & 10 & 0,29 \\
\hline Greece & $1971-2005$ & 9 & 0,26 & Suriname & $1971-2000$ & 4 & 0,13 \\
\hline Guatemala & $1971-2005$ & 15 & 0,43 & Swaziland & $1975-2005$ & 4 & 0,13 \\
\hline Guinea & $1977-1999$ & 5 & 0,22 & Sweden & $1971-2005$ & 6 & 0,17 \\
\hline Guyana & $1971-2005$ & 3 & 0,09 & Switzerland & 1971-2005 & 5 & 0,14 \\
\hline Haiti & $1975-2005$ & 17 & 0,55 & Syrian Arab Republic & $1975-1998$ & 5 & 0,21 \\
\hline Honduras & 1976-2005 & 6 & 0,20 & Tanzania & $1971-2005$ & 4 & 0,11 \\
\hline Hungary & $1971-2005$ & 6 & 0,17 & Thailand & $1971-2005$ & 10 & 0,29 \\
\hline Iceland & $1971-2005$ & 2 & 0,06 & Trinidad and Tobago & $1971-2005$ & 5 & 0,14 \\
\hline India & $1971-2005$ & 11 & 0,31 & Tunisia & $1976-2005$ & 6 & 0,21 \\
\hline Indonesia & $1974-2005$ & 5 & 0,16 & Turkey & $1971-2005$ & 10 & 0,29 \\
\hline Iran, Islamic Rep. & $1971-2005$ & 11 & 0,31 & Uganda & 1971-2005 & 8 & 0,23 \\
\hline Ireland & $1971-2005$ & 5 & 0,14 & United Kingdom & $1971-2005$ & 7 & 0,20 \\
\hline Israel & 1971-2005 & 7 & 0,20 & United States & $1971-2005$ & 3 & 0,09 \\
\hline Italy & $1971-2005$ & 3 & 0,09 & Uruguay & $1971-2005$ & 14 & 0,40 \\
\hline Jamaica & $1971-2005$ & 10 & 0,29 & Vanuatu & $1981-2005$ & 6 & 0,24 \\
\hline Japan & $1971-2005$ & 7 & 0,20 & Venezuela, RB & $1971-2005$ & 13 & 0,37 \\
\hline Jordan & $1971-2005$ & 5 & 0,14 & Zambia & $1971-2005$ & 9 & $18^{0,26}$ \\
\hline Kazakhstan & $1971-2005$ & 8 & 0,23 & Zimbabwe & 1971-1993 & 4 & $18_{0,17}$ \\
\hline
\end{tabular}


Appendix. Table A2. Variables used: definition and descriptive statistics

Variable

Governor changed, dummy

Share of term elapsed

Percentage of veto players who drop

Part of a year which is within 12 months after an

executive or legislative election

Coups d'etat, dummy

Transformed inflation

External debt of central government scaled to GDP (\%)

Government budget balance as \% of GDP

Average of 4 indicators (surrender of export

proceeds, multiple exchange rate, capital account restictions, current account restrictions)

New chief executive party, dummy

Change in the Polity democracy variable $>3$, dummy

First principal component of various instablity indicators

Private credit by deposit money banks and other

financial institutions scaled to GDP

Polarization* checks and balances

Party of chief executive is left-wing, dummy

Depreciation of the nominal exchange rate with respect to the US\$

A country is defined as experiencing a currency crisis when index covering the rate of change of the exchange rate and international currency reserves is one standard deviation greater than the index mean

Political constraints

Sum of exports and imports of goods and services measured as a share of gross domestic product

\begin{tabular}{|ccccc|}
\hline Obs. & Mean & Std.Dev. & Min & Max \\
\hline
\end{tabular}

\begin{tabular}{|c|c|c|c|c|}
\hline 4226 & 0.20 & 0.40 & 0.00 & 1.00 \\
\hline 4278 & 0.64 & 0.74 & 0.00 & 5.67 \\
\hline 4887 & 0.10 & 0.27 & 0.00 & 1.00 \\
\hline 6448 & 0.14 & 0.28 & 0.00 & 1.00 \\
\hline 4916 & 0.03 & 0.17 & 0.00 & 2.00 \\
\hline 4436 & 0.11 & 0.15 & -0.28 & 1.00 \\
\hline 3568 & 68.09 & 87.96 & 0.00 & 1598.22 \\
\hline 907 & 2.23 & 8.70 & -21.25 & 203.72 \\
\hline 3618 & 0.54 & 0.33 & 0.00 & 1.00 \\
\hline 7488 & 0.05 & 0.22 & 0.00 & 1.00 \\
\hline 7488 & 0.01 & 0.11 & 0.00 & 1.00 \\
\hline 5296 & 0.00 & 0.67 & -0.52 & 17.84 \\
\hline 3614 & 0.37 & 0.32 & 0.00 & 1.79 \\
\hline 4805 & 1.21 & 3.14 & 0.00 & 32.00 \\
\hline 6863 & 0.21 & 0.41 & 0.00 & 1.00 \\
\hline 5688 & 0.00 & 0.03 & -0.01 & 0.96 \\
\hline 4694 & 0.10 & 0.30 & 0.00 & 1.00 \\
\hline 5076 & 0.31 & 0.34 & 0.00 & 0.89 \\
\hline 4965 & 76.01 & 44.23 & 1.53 & 330.60 \\
\hline
\end{tabular}




\section{CESifo Working Paper Series}

(for full list see www.cesifo-group.de)

1980 Marco Pagano and Giovanni Immordino, Optimal Regulation of Auditing, May 2007

1981 Ludger Woessmann, Fundamental Determinants of School Efficiency and Equity: German States as a Microcosm for OECD Countries, May 2007

1982 Bas Jacobs, Real Options and Human Capital Investment, May 2007

1983 Steinar Holden and Fredrik Wulfsberg, Are Real Wages Rigid Downwards?, May 2007

1984 Cheng Hsiao, M. Hashem Pesaran and Andreas Pick, Diagnostic Tests of Cross Section Independence for Nonlinear Panel Data Models, May 2007

1985 Luis Otávio Façanha and Marcelo Resende, Hierarchical Structure in Brazilian Industrial Firms: An Econometric Study, May 2007

1986 Ondřej Schneider, The EU Budget Dispute - A Blessing in Disguise?, May2007

1987 Sascha O. Becker and Ludger Woessmann, Was Weber Wrong? A Human Capital Theory of Protestant Economic History, May 2007

1988 Erkki Koskela and Rune Stenbacka, Equilibrium Unemployment with Outsourcing and Wage Solidarity under Labour Market Imperfections, May 2007

1989 Guglielmo Maria Caporale, Juncal Cunado and Luis A. Gil-Alana, Deterministic versus Stochastic Seasonal Fractional Integration and Structural Breaks, May 2007

1990 Cláudia Costa Storti and Paul De Grauwe, Globalization and the Price Decline of Illicit Drugs, May 2007

1991 Thomas Eichner and Ruediger Pethig, Pricing the Ecosystem and Taxing Ecosystem Services: A General Equilibrium Approach, May 2007

1992 Wladimir Raymond, Pierre Mohnen, Franz Palm and Sybrand Schim van der Loeff, The Behavior of the Maximum Likelihood Estimator of Dynamic Panel Data Sample Selection Models, May 2007

1993 Fahad Khalil, Jacques Lawarrée and Sungho Yun, Bribery vs. Extortion: Allowing the Lesser of two Evils, May 2007

1994 Thorvaldur Gylfason, The International Economics of Natural Resources and Growth, May 2007

1995 Catherine Roux and Thomas von Ungern-Sternberg, Leniency Programs in a Multimarket Setting: Amnesty Plus and Penalty Plus, May 2007 
1996 J. Atsu Amegashie, Bazoumana Ouattara and Eric Strobl, Moral Hazard and the Composition of Transfers: Theory with an Application to Foreign Aid, May 2007

1997 Wolfgang Buchholz and Wolfgang Peters, Equal Sacrifice and Fair Burden Sharing in a Public Goods Economy, May 2007

1998 Robert S. Chirinko and Debdulal Mallick, The Fisher/Cobb-Douglas Paradox, Factor Shares, and Cointegration, May 2007

1999 Petra M. Geraats, Political Pressures and Monetary Mystique, May 2007

2000 Hartmut Egger and Udo Kreickemeier, Firm Heterogeneity and the Labour Market Effects of Trade Liberalisation, May 2007

2001 Andreas Freytag and Friedrich Schneider, Monetary Commitment, Institutional Constraints and Inflation: Empirical Evidence for OECD Countries since the 1970s, May 2007

2002 Niclas Berggren, Henrik Jordahl and Panu Poutvaara, The Looks of a Winner: Beauty, Gender, and Electoral Success, May 2007

2003 Tomer Blumkin, Yoram Margalioth and Efraim Sadka, Incorporating Affirmative Action into the Welfare State, May 2007

2004 Harrie A. A. Verbon, Migrating Football Players, Transfer Fees and Migration Controls, May 2007

2005 Helmuth Cremer, Jean-Marie Lozachmeur and Pierre Pestieau, Income Taxation of Couples and the Tax Unit Choice, May 2007

2006 Michele Moretto and Paolo M. Panteghini, Preemption, Start-Up Decisions and the Firms' Capital Structure, May 2007

2007 Andreas Schäfer and Thomas M. Steger, Macroeconomic Consequences of Distributional Conflicts, May 2007

2008 Mikael Priks, Judiciaries in Corrupt Societies, June 2007

2009 Steinar Holden and Fredrik Wulfsberg, Downward Nominal Wage Rigidity in the OECD, June 2007

2010 Emmanuel Dhyne, Catherine Fuss, Hashem Pesaran and Patrick Sevestre, Lumpy Price Adjustments: A Microeconometric Analysis, June 2007

2011 Paul Belleflamme and Eric Toulemonde, Negative Intra-Group Externalities in TwoSided Markets, June 2007

2012 Carlos Alós-Ferrer, Georg Kirchsteiger and Markus Walzl, On the Evolution of Market Institutions: The Platform Design Paradox, June 2007 
2013 Axel Dreher and Martin Gassebner, Greasing the Wheels of Entrepreneurship? The Impact of Regulations and Corruption on Firm Entry, June 2007

2014 Dominique Demougin and Claude Fluet, Rules of Proof, Courts, and Incentives, June 2007

2015 Stefan Lachenmaier and Horst Rottmann, Effects of Innovation on Employment: A Dynamic Panel Analysis, June 2007

2016 Torsten Persson and Guido Tabellini, The Growth Effect of Democracy: Is it Heterogenous and how can it be Estimated?, June 2007

2017 Lorenz Blume, Jens Müller, Stefan Voigt and Carsten Wolf, The Economic Effects of Constitutions: Replicating - and Extending - Persson and Tabellini, June 2007

2018 Hartmut Egger and Gabriel Felbermayr, Endogenous Skill Formation and the Source Country Effects of International Labor Market Integration, June 2007

2019 Bruno Frey, Overprotected Politicians, June 2007

2020 Jan Thomas Martini, Rainer Niemann and Dirk Simons, Transfer Pricing or Formula Apportionment? Tax-Induced Distortions of Multinationals' Investment and Production Decisions, June 2007

2021 Andreas Bühn, Alexander Karmann and Friedrich Schneider, Size and Development of the Shadow Economy and of Do-it-yourself Activities in Germany, June 2007

2022 Michael Rauscher and Edward B. Barbier, Biodiversity and Geography, June 2007

2023 Gunther Schnabl, Exchange Rate Volatility and Growth in Emerging Europe and East Asia, June 2007

2024 Erkki Koskela and Ronnie Schöb, Tax Progression under Collective Wage Bargaining and Individual Effort Determination, June 2007

2025 Jay Pil Choi and Marcel Thum, The Economics of Politically Connected Firms, June 2007

2026 Jukka Pirttilä and Roope Uusitalo, Leaky Bucket in the Real World: Estimating Inequality Aversion Using Survey Data, June 2007

2027 Ruslan Lukach, Peter M. Kort and Joseph Plasmans, Strategic R\&D with Knowledge Spillovers and Endogenous Time to Complete, June 2007

2028 Jarko Fidrmuc, Neil Foster and Johann Scharler, Labour Market Rigidities, Financial Integration and International Risk Sharing in the OECD, June 2007

2029 Bernardina Algieri and Thierry Bracke, Patterns of Current Account Adjustment Insights from Past Experience, June 2007 
2030 Robert Dur and Hein Roelfsema, Social Exchange and Common Agency in Organizations, June 2007

2031 Alexander Libman and Lars P. Feld, Strategic Tax Collection and Fiscal Decentralisation: The Case of Russia, June 2007

2032 Øystein Foros, Hans Jarle Kind and Greg Shaffer, Resale Price Maintenance and Restrictions on Dominant Firm and Industry-Wide Adoption, June 2007

2033 Jan K. Brueckner and Kurt Van Dender, Atomistic Congestion Tolls at Concentrated Airports? Seeking a Unified View in the Internalization Debate, June 2007

2034 Viet Do and Ngo Van Long, International Outsourcing under Monopolistic Competition: Winners and Losers, June 2007

2035 Nadia Fiorino and Roberto Ricciuti, Determinants of Direct Democracy, June 2007

2036 Burkhard Heer and Alfred Maussner, Inflation and Output Dynamics in a Model with Labor Market Search and Capital Accumulation, June 2007

2037 Konstantinos Angelopoulos, Jim Malley and Apostolis Philippopoulos, Public Education Expenditure, Growth and Welfare, June 2007

2038 Maarten Bosker, Steven Brakman, Harry Garretsen and Marc Schramm, Adding Geography to the New Economic Geography, June 2007

2039 Steffen Henzel, Oliver Hülsewig, Eric Mayer and Timo Wollmershäuser, The Price Puzzle Revisited: Can the Cost Channel Explain a Rise in Inflation after a Monetary Policy Shock?, July 2007

2040 Rosario Crinò, Service Offshoring and White-Collar Employment, July 2007

2041 Carsten Hefeker and Michael Neugart, Labor Market Regulation and the Legal System, July 2007

2042 Bart Cockx and Muriel Dejemeppe, Is the Notification of Monitoring a Threat to the Unemployed? A Regression Discontinuity Approach, July 2007

2043 Alfons J. Weichenrieder, Profit Shifting in the EU: Evidence from Germany, July 2007

2044 Annika Alexius and Bertil Holmlund, Monetary Policy and Swedish Unemployment Fluctuations, July 2007

2045 Axel Dreher, Jan-Egbert Sturm and Jakob de Haan, Does High Inflation Cause Central Bankers to Lose their Job? Evidence Based on a New Data Set, July 2007 